\title{
Three Focuses of Primary and Middle School Students' Core Value Education
}

\author{
Baoquan Huang \\ Zhoukou Normal University, Postcode: 466001. \\ Email:1339652422@qq.com
}

\begin{abstract}
Core values are the soul of a country's cultural soft power and the focus of cultural construction. Elementary and middle school students are the future of the country and the hope of the nation. Affected by the market economy and multiculturalism, elementary and middle school students have prominent problems such as confusion in choice of values, nothingness in values, and collapse of values. Three key points should be grasped in the education of core values for elementary and middle school students: consolidate the guarantee of the system and mechanism; strengthen the practice and self-education of elementary and middle school students; build a cooperative education network for families, schools and society.
\end{abstract}

Keywords: Primary and middle school students; education of core values;

With the continuous development of my country's market economy and the influence of the world's multiculturalism, some elementary and middle school students are faced with the confusion of value choices, and some elementary and middle school students have lost their values and collapsed in their direction. Primary and middle school students are in a critical period of value formation and establishment, with great plasticity. Therefore, the education of the core values of primary and middle school students is related to the future development and the future destiny of the country. The education of core values for elementary and middle school students is a systematic project and must be promoted as a whole. It is necessary to internalize the core values by consolidating the guarantee of the education system, strengthening practical development and self-education, building a network of family, school and social cooperative education. The spiritual pursuit of elementary and middle school students is externalized into the conscious action of elementary and middle school students, which truly implements the education of core values of elementary and middle school students.

\section{Tamping the System and Mechanism Guarantee of Primary and Middle School Students' Core Value Education}

First, establish an organizational leadership mechanism for core value education. Under the unified leadership of the party committee, all kinds of schools and administrative departments should establish leading groups and organizations for primary and secondary school students' core values education, integrate the collective forces of education, publicity, public security and other departments, and jointly manage the core values of primary and secondary school students. The government must grasp the direction of the core values of primary and middle school students from a macro and overall perspective, take the socialist core values as the guide, formulate documents and guidelines for the education of core values of primary and middle school students, improve the rules and regulations of all walks of life, and improve the civic conventions and township regulations. We must mobilize various publicity media to create a good atmosphere for the education of the core values of primary and middle school students in the whole society, and guide the majority

Copyright (C) 2020 Baoquan Huang

doi: 10.18282/le.v9i5.1226

This is an open-access article distributed under the terms of the Creative Commons Attribution Non-Commercial License

(http://creativecommons.org/licenses/by-nc/4.0/), which permits unrestricted non-commercial use, distribution, and reproduction in any medium, provided the original work is properly cited. 
of students to study, understand, and practice the core values of socialism.

Second, establish a long-term mechanism for the education of core values for primary and middle school students. The formation of the core values of primary and middle school students is a long-term, gradual and complicated process that requires the support of a long-term education mechanism. Each school and administrative department should formulate specific implementation opinions and implementation rules for core values education, constantly improve and perfect the core values education plan, and integrate the core values education work of primary and middle school students into the overall national education overall development plan and the long-term goal of school development, so that the core Values continue to run through pre-school education, basic education, secondary education, higher education and other fields, and gradually form a scientific and reasonable educational content, and adopt effective methods and measures to implement the core value education work into specific education, teaching, service, management, etc. All links form a long-term mechanism for core values education.

Third, establish a scientific evaluation feedback mechanism for the education of core values for primary and middle school students. In order to achieve the ideal effect of the core values education of primary and middle school students, we must continuously evaluate and feedback the effect of core values education, so as to optimize and adjust the ways, strategies and forms of core values education according to the physical and mental characteristics and internal and external environments of primary and secondary students. To this end, the relevant departments should build a scientific and rational core value education method system, build a dynamic monitoring platform for the core value education effect, and comprehensively monitor the forms, processes, and models that affect the core value education effect of primary and middle school students, and based on the feedback results Constantly adjust and revise the various elements of core values education, so as to continuously optimize the internal and external transmission and acceptance mechanisms of core values education for primary and middle school students, and improve the effectiveness of core values education.

\section{Strengthen the practice and self-education of the core values education of primary and middle school students}

The education and development of core values for primary and middle school students is a process of internalization and externality. Whether the primary and secondary school students can really make the core values take root in their hearts and become a kind of consciousness, the key lies in the practice and self-education of the primary and secondary school students.

The so-called "Dao cannot sit on the theory, Germany cannot talk empty talk". Primary and middle school students should insist on the unity of knowledge and action, insist on starting from their own, and implement the core values. The majority of primary and middle school students should take the difficult environment as an opportunity to hone themselves, move forward step by step, and consciously practice core values. Elementary and middle school students should continuously reflect on the requirements of core values in combination with their own learning and life practices, so that the core values are truly reflected in actions and effects, and transform the core values into the elementary and middle school students' emotional identity, daily behavior habits and conscious actions. The effect of education on core values of primary and middle school students is not only influenced and influenced by external factors, but also reflected in the self-construction and self-learning of primary and secondary school students. Only through educators' own active learning and internalized acceptance activities can core values play a role. To achieve the corresponding effect, therefore, primary and middle school students should continue to strengthen their recognition of core values by strengthening self-education. The majority of primary and secondary school students should explore the potential of internal self-education, insist on continuous reflection, introspection, and constantly enhance the internal driving force of core values education.

\section{Construct a collaborative education network for school education, family education and social education}

First, give play to the guiding role of school education. Schools play a fundamental role in the education of core 
values for primary and middle school students. To strengthen the guiding role of schools at all levels and all types in the education of core values for primary and middle school students, teachers should take the lead in setting an example, consciously practice the core values, and effectively ensure that the core values of primary and secondary school students are educated in schools, teaching materials, classrooms, and minds. Schools can formulate school rules, school mottos, and student codes in accordance with the core values of socialism to form a good school spirit for the education of core values for primary and middle school students. Qualified schools can compile school-based textbooks and incorporate the core values in the textbooks, so that the education of core values for primary and middle school students has become an important task for the school's morals.

Second, create a good family atmosphere for core value education. Parents are the first teachers of elementary and middle school students. Parents should always establish the awareness of core values education of elementary and middle school students, consciously work hard on the core values education of elementary and middle school students, create a good family style and atmosphere, and actively guide elementary and middle school students to practice core values. Give play to the role of family education in the education of the core values of primary and middle school students. In addition, we must give play to the role of parents in teaching and demonstrating, set an example for primary and middle school students everywhere, and educate children with correct actions, ideas, and methods. We must be good at teaching children to appreciate the truth, goodness, and beauty, and stay away from false and evil ugliness. Parents can also According to the core values, formulate family rules and rules in the new era to guide primary and middle school students to consciously abide by them.

Third, promote a good social atmosphere. All sectors of the society should increase the education and promotion of core values, take advantage of the unique advantages of information technology in the new era, and use new media technologies such as newspapers, television, WeChat, and the Internet to vigorously promote and promote core values throughout the society, so that primary and secondary school students can be everywhere. Affected by the core values, it creates a good public opinion atmosphere in the whole society where everyone knows the core values, promotes the core values, and advocates the core values.

\section{References}

1. Fu Lianzhen. Cultivation strategies for core values based on the "Code for Primary and Secondary School Students"[J]. Journal of Dalian Education University, 2019, 35(03): 56-57.

2. Wei Xiaochun. Strengthen the cultivation of the socialist core values of primary and secondary school students[J]. Democracy, 2016(09): 8-10.

3. Suggestions on countermeasures for cultivating and practicing the core values of socialism for primary and middle school students[J]. Xianfeng, 2015(10): 53-55. 